\title{
EFEKTIVITAS MULTIPLE FAMILY THERAPY UNTUK PENURUNAN BEBAN PENDAMPING ORANG DENGAN SKIZOFRENIA
}

\author{
Andini Avriyani' ${ }^{1}$, Kamsih Astuti2, Siti Noor Fatmah Lailatusifah ${ }^{3}$ \\ ${ }^{123}$ Fakultas Psikologi, Universitas Mercu Buana Yogyakarta \\ ${ }^{1}$ Andini.avriyani@gmail.com
}

\begin{abstract}
Abstrak
Penelitian ini bertujuan untuk mengetahui efektivitas Multiple Family Therapy (MFT) untuk penurunan beban pada pendamping orang dengan skizofrenia (ODS). Hipotesis yang diajukan dalam penelitian ini adalah ada perbedaan beban antara pendamping yang diberi MFT dengan pendamping yang tidak diberikan MFT. Subjek yang mendapatkan MFT mengalami penurunan beban pendamping daripada yang tidak mendapatkan MFT.Subjek penelitian sebanyak 6 orang pendamping yaitu 3 orang pada kelompok eksperimen dan 3 orang pada kelompok kontrol. Beban pendamping diukur dengan Zarit Burden Interview (ZBI) yang telah diterjemahkan dalam bahasa Indonesia. Hasil analisis dengan Independent Sample t Testdiperoleh nilai t : 3,343; $\mathrm{p}<0,05$,dan hasil Paired Sample T Test diperoleh skor t hitung sebesar 37,000; $\mathrm{p}<0,05$. Dari hasil penelitian ini diketahui bahwa pendamping ODS yang mendapatkan MFT memiliki beban pendamping yang lebih rendah daripada pendamping ODS yang tidak mendapatkan MFT. Dengan demikian dapat disimpulkan bahwa MFT dapat menurunkan beban pada pendamping orang dengan skizofrenia.
\end{abstract}

Kata kunci: beban pendamping, multiple family therapy

\section{THE EFFECTIVENESS OF MULTIPLE FAMILY THERAPY FOR DECREASING LOADS OF SKIZOFRENIA CAREGIVER}

\author{
Andini Avriyani' ${ }^{1}$, Kamsih Astuti2, Siti Noor Fatmah Lailatusifah ${ }^{3}$ \\ ${ }^{123}$ Fakultas Psikologi, Universitas Mercu Buana Yogyakarta \\ 1'Andini.avriyani@gmail.com
}

\begin{abstract}
This study aims to determine the effectiveness of Multiple Family Therapy (MFT) to decrease the burden on schizophrenia caregiver. The hypothesis proposed in this study is that there is a difference of load between the caregiver given MFT with the caregiver that is not given MFT. Subjects who get MFT have decreased caregiver loads than those who does not get MFT. The research subjects were 6 counselors which was 3 people for the experimental group and 3 people for the control group. The caregiver load was measured with Zarit Burden Interview (ZBI) which has been translated into Indonesian. The result of analysis with Independent Sample t Test obtain $t$ value: 3,$343 ; \mathrm{P}<0,05$, and result of Paired Sample T Test obtaint value score equal to 37,000; $\mathrm{P}$ $<0.05$. From the results of this study, it is known that the ODS caregiver that obtains MFT has a lower caregiver load than the ODS counterpart that does not get MFT. Thus it can be concluded that MFT can reduce the burden on the schizophrenia caregiver.
\end{abstract}

Keywords: caregiver load, multiple family therapy 


\section{PENDAHULUAN}

Skizofrenia adalah salah satu gangguan mental yang cukup banyak terdapat di Indonesia. Gangguan skizofrenia di Indonesia pada saat ini diduga dialami 6-19 orang per 1000 penduduk, apabila jumlah penduduk Indonesia berkisar 200 juta jiwa, maka penderitanya tidak kurang dari 1,2 juta jiwa (Permanasari \& Tunggal, 2010).

Meskipun orang dengan skizofren (ODS) membaik setelah penanganan, mereka cenderung akan mengalami berbagai kesulitan sepanjang hidupnya (Durand \& Barlow, 2007), sehingga mereka membutuhkan orang lain untuk mendampingi atau merawatnya, tergantung tingkat keparahan penyakit. Hal tersebut dapat menimbulkan stres tidak hanya bagi ODS, namun juga bagi caregiver atau orang yang mendampinginya (dalam penelitian ini seterusnya akan disebut sebagai pendamping). Pendamping didefinisikan sebagai orang yang memberikan bantuan pada orang lain yang membutuhkan (Lubkin \& Larsen, 2006). Pendamping dibedakan menjadi dua jenis, yakni pendamping formal dan pendamping informal. Pendamping formal merupakan tenaga profesional yang bertugas untuk mendampingi orang lain yang mengalami gangguan fisik dan/atau mental. Pendamping informal merupakan seseorang yang merawat orang lain tanpa dibayar dan biasanya mempunyai hubungan pribadi dengan orang yang dirawat, seperti keluarga atau teman (Lubkin \& Larsen, 2006).

Chakrabarti (2011) mengungkapkan bahwa di Asia, keluarga hampir selalu dilibatkan dalam perawatan gangguan mental. Keluarga merupakan bagian yang tidak dapat dipisahkan dari sistem perawatan bagi orang-orang dengan penyakit mental kronis (Kumari, Singh, Verma, Verma, \& Chaudhury; 2009). Oleh karena itu, dalam penelitian ini penulis memfokuskan pada keluarga yang berperan sebagai pendamping informal bagi ODS. Schene dan para koleganya (dalam Talwar \& Matheiken, 2010), mengemukakan beberapa hal yang dialami dan harus dilakukan pendamping selama mendampingi pasien, meliputi: suasana rumah tegang; pertengkaran yang disebabkan oleh pasien; menjaga atau mengawasi apabila pasien melakukan tindakan yang berbahaya, mencederai diri sendiri, dan mengkonsumsi obat yang ilegal; memastikan pasien tidur yang cukup; mencemaskan keselamatan pasien; mendorong pasien untuk mengurus dirinya sendiri; mendorong pasien untuk makan yang cukup; mendorong pasien untuk melakukan kegiatan, bangun pagi; khawatir akan keuangan pasien apabila keluarga tidak mampu menopang secara ekonomi lagi; khawatir akan masadepan pasien dan masa depannya sendiri.

Dinamika permasalahan dan kejadian yang dihadapi pendamping selama merawat ODS dapat membawa dampak yang berbeda bagi tiap pendamping. Dampak positif menjadi pendamping menurut Yamada, Hinrichsen, Hernandez, dan Pollack (dalam Widyanti, 2009) antara lain adalah munculnya perasaan dihargai, berguna (sense of usefullness), meningkatkan kualitas hubungan dengan orang yang didampingi menjadi lebih dekat dan lebih baik. Menurut Yamada (dalam Widyanti, 2009) merawat atau mendampingi juga dapat menggantikan perasaan gagal akibat kegagalan pernikahan, menjanda, atau karir yang tidak 
memuaskan. Adapun dampak negatif dalam mendampingi, yakni dapat menimbulkan stressor yang berkepanjangan dan menyebabkan cukup banyak beban bagi pendamping.

Definisi beban pendamping secara umum dapat diartikan sebagai efek atau konsekuensi negatif yang ditimbulkan selama mendampingi ODS. Dillehay \& Sandys (1990) mendefiniskan beban sebagai keadaan psikologis yang muncul sebagai gabungan/paduan dari pekerjaan fisik dan emosional, tekanan sosial, dan keterbatasan finansial yang merupakan konsekuensi dari merawat pasien.

Beban pendamping bila tidak diatasi dapat membawa dampak bagi ODS selaku yang didampingi ataupun bagi pendamping itu sendiri. Beban sebagai pendamping antara lain dapat memengaruhi kondisi kesehatan mereka, keadaan emosional, maupun kondisi ekonomi. Hal ini dapat mendatangkan efek yang negatif pada kualitas hidup pendamping, dan lebih jauh lagi dapat memengaruhi cara pendamping dalam merawat atau mendampingi ODS, seperti perawatan atau pengasuhan yang tidak maksimal, kesalahan dalam merawat atau mendampingi, atau kekerasan kepada ODS, dimana hal itu dapat menimbulkan kekambuhan bagi ODS. Apabila ODS mengalami kekambuhan, tentunya waktu, tenaga, uang yang dibutuhkan akan lebih besar lagi, hal ini dapat menambah beban lagi bagi pendamping.

Intervensi yang melibatkan keluarga memerlihatkan hasil yang positif dalam mereduksi beban keluarga sebagai pendamping (Chakrabarti, 2011). Intervensi pada keluarga umumnya terdiri dari strategi keterlibatan, psikoedukasi mengenai penyakit atau gangguan yang dialami penderita, pelatihan penanggulangan dan kemampuan memecahkan masalah untuk menurunkan stres dalam keluarga (Smith, Weston, \& Lieberman, 2009; Adams, Wilson, Bagnall, 2000; Nichols \& Schwartz, 2007). Multiple Family Therapy(MFT) adalah terapi yang melibatkan beberapa keluarga dalam satu terapi bersama-sama secara teratur (Asen, 2002; Gurman \& Kniskern, 1991). MFT melibatkan beberapa keluarga dalam kontek terapeutik untuk bekerja bersama-sama mengatasi setiap masalah tertentu (Asen \& Scholz, 2010). Ide untuk melibatkan beberapa keluarga pertama kali dipelopori oleh Laqueur dan para koleganya (Asen, 2002) dengan melibatkan pasien skizofrenia, dimana Laqueur dan koleganya mengajak keluarga-keluarga pasien skizofrenia untuk terlibat dalam pengelolaan pasien kronis, mereka dihadapkan pada praktek/penerapan yang ada di rumah sakit dalam menghadapi pasien kronis.

Tujuan utama Laqueur dan koleganya mengelompokkan keluarga pasien skizofrenia dalam satu kelompok adalah agar mereka memahami beberapa perilaku yang bermasalah dari pasien, dengan tidak hanya fokus pada simtom yang dialami anggota keluarga mereka yang sakit, namun juga memahami simtom dari anggota keluarga lain, sehingga mereka bisa belajar dari pengalaman keluarga lain.

Menurut Le Grange \& Eisler (dalam Gabel dkk., 2014), manfaat dari MFT antara lain meningkatkan kemampuan komunikasi, mengurangi perasaan dikucilkan/terisolasi, mengurangi stigma negatif akan penyakit pasien, 
dan memungkinkan keluarga untuk mendapatkan ide/pandangan yang berbeda dalam lingkungan yang mendukung. Menurut Gabel dan para koleganya (Gabel dkk., 2014), MFT memberikan dampak positif untuk meringankan gejala depresi.

Kehadiran keluarga lain dengan permasalahan dan kesulitan yang sama dalam MFT, mendorong orang untuk membandingkan keadaannya dan membantu satu sama lain untuk berbagi dilema akrab dan membahas cara-cara mereka masing-masing untuk menemukan solusi yang berbeda. Berbagi pengalaman membantu keluarga mengurangi perasaan terisolasi, mengatasi perasaan diasingkan, atau stigma, baik hanya perasaannya saja ataupun memang realita. Keluarga akan menjadi kurang defensif saat mereka merasa "berada di situasi yang sama", hal ini dapat membuat individu menjadi lebih terbuka dan bercermin dari keluarga lain. Individu seperti melihat diri mereka sendiri pada org lain (Asen \& Scholz, 2010).

MFT dalam penelitian ini dikembangkan dengan mengacu pada konsep dari terapi keluaga yang dikemukakan Davison dan para koleganya (2006), kemudian diadaptasi ke dalam format kelompok, dikombinasikan dengan latihan relaksasi, serta disesuaikan dengan fokus utama penelitian, yakni untuk mengatasi beban pendamping. Tahap-tahap terapi yang akan digunakan dalam modul terapi penelitian ini, antara lain: a) Edukasi, memberikan informasi pada anggota keluarga mengenai hal-hal yang berkaitan dengan skizofrenia; b) Reframing, membantumengubah cara pandang atau persepsi dalam menghadapi permasalahan atau kesulitan selama menangani ODS, asumsi yang mendasari strategi reframing adalah bahwa keyakinan, pemikiran, dan persepsi seseorang itu bisa menciptakan kesulitan emosional dan juga emosi yang salah, dalam MFT individu dapat belajar dari pengalaman keluarga lain; c) Strategi coping, membantu memperbaiki keterampilan keluarga dalam mengatasi masalah, dalam menghadapi situasi yang menimbulkan perasaan tertekan, stres, membantu keluarga untuk memahami bahwa permasalahan membutuhkan penanganan, memahami dampak stres bagi diri sendiri, memahami beberapa cara coping yang sebaiknya dilakukan dan dihindari. Pada dasarnya strategi coping diharapkan dapat membantu peserta menyesuaikan diri dengan keadaan yang tidak menguntungkan, yang dirasa membebani atau melebihi kemampuan sumber daya individu; d) Komunikasi, membantu memperbaiki pola komunikasi dengan ODS, memberi gambaran kesalahan komunikasi, memfokuskan bagaimana mengajari keluarga berbagai cara mengekspresikan perasaan positif dan negatif secara konstruktif, empatikdan tidak menuntut, bukan dengan cara saling menuding, mengkritik, atau terlalu melindungi; e) Motivasi dan relaksasi, memotivasi keluarga sebagai pendamping dalam merawatODS, menanamkan harapan kepada pasien dan keluarga akan kondisi yang lebih baik dan memotivasi keluarga untuk mencari serta memanfaatkan sumber dukungan lain,dilanjutkan dengan mengajarkan relaksasi, sebagai salah satu cara untuk meredakan stres yang dialami sewaktuwaktu. Penelitian ini bertujuan untuk mengetahui efektivitasMFT untuk penurunan beban pendamping orang dengan skizofrenia. 


\section{METODE}

Variabel tergantung dalam penelitian ini adalah beban pendamping orang dengan skizofrenia, sedangkan variabel bebasnya adalah MFT. Subjek inklusi dalam penelitian ini antara lain: (a) memiliki anggota keluarga yang mengalami skizofrenia, dan telah mendampingi ODS lebih dari 1 tahun, (b) tidak sedang mendapatkan psikoterapi lain pada waktu yang bersamaan dengan penelitian ini berlangsung, dan belum pernah mengikuti MFT, (c) mampu membaca dan menulis, karena dalam proses terapi akan dibutuhkan dua kemampuan tersebut, (d) subjek memiliki skor beban minimal sedang pada pengukuran fase pretest, (e) bersedia mengikuti proses terapi dari awal hingga akhir penelitian

Pengumpulan data variabel tergantung dalam penelitian ini menggunakan metode skala, yaitu Skala Zarit Burden Interview yangtelah diterjemahkan dalam bahasa Indonesia \{ZBI mampu mendeteksi adanya caregiver dengan beban perawatan sebesar $75.7 \%$ (sensitivitas) dan mendeteksi adanya caregiver tanpa beban perawatan sebesar $83.6 \%$ (spesifitas), dengan keakuratan pengelompokan tersebut sebesar $79.2 \%$, serta nilai cronbach alpha adalah 0,837 , yang berkisar antara 0,817 sampai dengan $0,842$,$\} .$

Analisis data yang digunakan untuk menguji hipotesis dalam penelitian ini adalah Independent Sample $\mathrm{T}$ Test untuk menguji/membandingkan perbedaan rata-rata dari dua kelompok sampel yang independen (Priyatno, 2012). Kelompok yang diuji dalam penelitian ini yakni kelompok eksperimen dan kelompok kontrol.

Analisis selanjutnya yang digunakan adalah Paired Sample T Test, untuk menguji perbedaan rata-rata dari dua kelompok sampel yang berpasangan/berhubungan (Priyatno, 2012; Santoso, 2014). Sampel berpasangan (paired sample) adalah sebuah sampel dengan subjek yang sama, namun mengalami dua perlakuan atau pengukuran yang berbeda. Analisis ini akan digunakan untuk menguji perbedaan pretest dan posttest pada kelompok eksperimen.

\section{HASIL DAN PEMBAHASAN}

Data yang digunakan sebagai dasar hipotesis yaitu data yang diperoleh dari hasil pretestdan posttestpada kelompok kontrol dan kelompok eksperimen.

\section{Tabel 1. Deskripsi data mean beban pendamping}

\begin{tabular}{lll}
\hline Kelompok & Pretest & Posttest \\
\hline KE56,67 & 44,33 & \\
KK & 54,33 & 58,67
\end{tabular}

Hasil uji beda dengan menggunakan gained score untuk selisih pretest-posttest menunjukkan bahwa ada perbedaan beban pendamping antara sebelum diberikan MFT dan setelah diberi MFT dengan nilai t: 3,343; $\mathrm{p}<0,05$. Hal ini menunjukkan bahwa ada perbedaan beban pendamping pada kelompok eksperimen dengan kelompok control.

Analisis uji hipotesis selanjutnya yang digunakan adalah Paired Sample T Test. 
Tabel 2. Hasil Uji Hipotesis Paired Sample T Test KE

\begin{tabular}{ll}
\hline & $\begin{array}{l}\text { Pretest } \\
\text { Posttest }\end{array}$ \\
\hline T & 37,000 \\
Sig. (1 tailed) & 0,0005 \\
\hline
\end{tabular}

Hasil analisis pada kelompok eksperimen dengan paired sample t test menunjukkan bahwa ada perbedaan beban pendamping antara sebelum MFT dengan setelah MFT.Dari nilai mean dapat dilihat bahwa mean setelah perlakuan (posttest) pada kelompok eksperimen lebih rendah daripada mean sebelum perlakuan (pretest), dengan ini dapat disimpulkan pula bahwa MFT dapat menurunkan beban pendamping ODS pada kelompok eksperimen.

\section{HASIL DAN PEMBAHASAN}

Hasil penelitian ini menunjukkan bahwa MFT dapat menurunkan beban pendamping ODS. Intervensi yang melibatkan keluarga memperlihatkan hasil yang positif dalam mereduksi beban keluarga sebagai pendamping (Chakrabarti, 2011). MFT berisi tentang edukasi mengenai penyakit dan gangguan ODS, reframing, strategi coping, komunikasi, motivasi, dan latihan relaksasi.

Adanya edukasi mengenai penyakit dan gangguan ODS dapat meningkatkan pengetahuan para pendamping, sehingga dapat mempengaruhi sikap para pendamping dalam mendampingi dan menilai keadaan ODS. Adanya pengetahuan ini membuat para pendamping merasa tahu dengan kondisi pasien sehingga lebih mampu merawat ODS, lebih nyaman dan tenang dalam merawat ODS. Hal ini sesuai dengan hasil penelitian Smith dan Birchwood (Lowyck dkk, 2004) bahwa mengenai informasi tentang penyakit dan konsekuensi dari penyakit pasien serta berbagi kekhawatiran dengan pihak lain dapat menurunkan beban keluarga. Kemudian adanya reframing, membantu pada pendamping untuk dapat membingkai ulang mengenai ODS dan segala permasalahannya. Pendamping dapat mengubah persepsinya terhadap ODS, tidak lagi selalu menyalahkan ODS tetapi dapat mengubah pandangan ke depan untuk lebih difokuskan pada upaya untuk membuat kondisi ODS menjadi lebih baik.Pada dasarnya reframing adalah pencarian makna baru dari sesuatu yang sebelumnya dimaknai secara tertentu, mengubah sudut pandang tanpa mengubah kejadiannya tu sendiri (Nursalim, 2013).

Dalam MFT ini pendamping diberi ketrampilan dalam mengatasi masalah, menghadapi situasi yang dapat menimbulkan stress, memahami cara coping yang sebaiknya dilakukan atau dihindari. Dengan kemampuan coping ini pendamping dapat menyesuaikan diri dan menghadapi situasi yang tidak menguntungkan, dirasa membebani, atau melebih sumber dayanya. Sebagai contoh dengan cara mendekatkan diri pada Tuhan, atau melalukan relaksasi membuat pendamping merasa lebih plong dalam menjalani harinya. 
Sesi selanjutnya pendamping dibantu untuk memperbaiki pola komunikasi dan ketrampilan keluarga dalam mengatasi masalah, mengekspresikan perasaan secara konstruktif, empatik dan tidak menuntut. Kemampuan ini membuat pendamping memperlakukan ODS dengan cara yang tepat, tidak mengabaikan dan dapat memberi perhatian, dan memberi ODS kesibukan yang dapat dilakukannya.

Sesi terakhir berisi motivasi dan latihan relaksasi. Terapis memotivasi keuarga sebagai pendamping dalam merawat ODS, menanamkan harapan pada keluarga, dan mengajari latihan relaksasi sebagai salah satu cara meredakan stress. Dengan demikian, MFT dapat membuat pendamping memiliki pengetahuan dan kemampuan untuk dapat merawat ODS, sehingga dapat memperlakukan ODS dengan cara yang tepat dan menghadapi situasi hidup bersama ODS dengan cara-cara yang konstruktif.

Dalam proses MFT keluarga akan menjadi kurang defensif saat mereka merasa "berada di situasi yang sama", hal ini membuat individu menjadi lebih terbuka dan bercermin dari keluarga lain. Individu seperti melihat diri mereka sendiri pada orang lain (Asen \& Scholz, 2010). Manfaat dalam MFT sesuai dengan tujuan utama yang dilakukan Laqueur dan rekan kerjanya (dalam Asen, 2002) yakni dengan mengelompokkan keluarga pasien skizofrenia dalam satu kelompok terapi, mereka tidak hanya fokus pada simtom yang dialami anggota keluarga mereka yang sakit, namun juga memahami simtom dari anggota keluarga lain, sehingga mereka bisa belajar dari pengalaman keluarga lain. Berbagi pengalaman membantu keluarga mengurangi perasaan terisolasi, mengatasi perasaan diasingkan, atau stigma, baik hanya perasaannya saja ataupun memang realita.

Menurut Gabel dan para koleganya (Gabel dkk., 2014), MFT memberikan dampak positif untuk meringankan gejala depresi. Intervensi yang melibatkan keluarga memerlihatkan hasil yang positif dalam mereduksi beban keluarga sebagai pendamping (Chakrabarti, 2011).

Dari hasil analisis di atas diketahui bahwa secara keseluruhan subjek dalam kelompok eksprimen mengalami perubahan antara sebelum dan sesudah diberikan MFT. Perubahan perubahan tersebut antara lain bahwa subjek terlihat lebih percaya diri, termotivasi,berusaha memahami kondisi ODS lebih baik, dan belajar cara meredakan stres yang dirasakan sehingga tidak menumpuk dalam hatinya yang dapat menyebabkan penurunan kondisi fisik.

\section{KESIMPULAN}

Berdasarkan hasil penelitian dan pembahasan dapat disimpulkan bahwa MFT dapat menurunkan beban pendamping orang dengan skizofrenia. MFT melibatkan lebih dari satu keluarga dalam proses terapinya, sehingga keluarga dapat melihat keadaan ataupun permasalahan yang dialami oleh keluarga lain, dan oleh karena itu mereka dapat belajar dan bercermin dari keluarga lain. Dalam proses MFT juga ada kesempatan bagi keluarga untuk 
menceritakan pengalaman dan permasalahan yang dihadapi selama mendampingi ODS, lalu didiskusikan bersama dan diberikan pemahaman yang benar mengenai penyakit oleh terapis, sehingga keluarga sebagai pendamping ODS memiliki pemahaman yang lebih baik mengenai keadaan ODS, lebih memahami bagaimana bersikap kepada ODS, mengetahui bagaimana menangani permasalahan dengan lebih baik lagi, serta belajar berdamai dengan keadaan, dan akhirnya dapat mereduksi beban yang dirasakannya.

Berdasarkan hasil penelitian dan pembahasan yang dilakukan, disarankan :

1. Bagi keluarga

Pengalaman yang diperoleh di MFT diharapkan dapat diterapkan oleh keluarga dalam menjalani perannya sebagai pendamping ODS di rumah. Hal itu dimaksudkan supaya dalam menjalani peran sebagai pendamping tidak membawa dampak yang negatif bagi keluarga dan ODS.

\section{Bagi pihak rumah sakit}

Diharapkan dapat dijadikan sebagai bahan pertimbangan untuk menerapkan MFT di rumah sakit pada keluarga pasien secara berkala, sehingga keluarga yang mendampingi pasien tidak hanya berbagi dengan tenaga profesional saja, namun juga dengan keluarga lainnya.

3. Bagi peneliti selanjutnya

Penelitian ini masih banyak kekurangannya, diharapkan bagi peneliti selanjutnya dapat melakukan yang lebih maksimal lagi dengan mempertimbangkan berbagai faktor yang memengaruhi beban, serta melakukan pengukuran terhadap komponen intervensi sebelum intervensi itu diberikan, untuk menghindari over-claiming. Mengingat masih sedikit penelitian di Indonesia mengenai intervensi terhadap beban pendamping ODS sejauh yang peneliti tahu, diharapkan peneliti lain dapat mengembangkannya lagi misalnya dengan melibatkan pasien dalam terapi, atau membandingkan terapi mana yang paling efektif untuk mereduksi beban.

\section{DAFTAR PUSTAKA}

Adams, C., Wilson, P., Bagnall, A-M. (2000). Psychosocial Interventions for Schizophrenia, Quality in Health Care, Effectiveness Bulletins, 9, 251-256. NHS Centre for Reviews and Dissemination, University of York.

Asen, E. (2002). Multiple Family Therapy, An Overview. Journal of Family Therapy, 24, 3-16.

Asen, E. \& Scholz, M. (2010). Multi-Family Therapy; Concepts and Techniques. New York: Routledge: Taylor \& Francis Group.

Chakrabarti, S. (2011). Family Interventions in Schizophrenia; Issues of Relevance for Asian Countries. World Journal of Psychiatry, Desember, Vol.1 (1), 4-7.

Durand, V. M. \& Barlow, D. H. (2007). Intisari Psikologi Abnormal, Edisi ke-empat, Buku ke-dua. Yogyakarta: Pustaka Pelajar.

Gabel, K., Pinhas, L., Eisler, I., Katzman, D., Heinmaa, M. (2014) The Effect of Multiple Family Therapy on Weight Gain in Adolescents withAnorexia Nervosa: Pilot Data.Journal of The Canadian Academy of Child and Adolescent Psychiatry, 23:3.

Kumari, S., Singh, A. R., Verma, A. N., Verma, P. K., Chaudhury, S. (2009). Subjective burdenon spouses of schizophrenia patients. Industrial Psychiatry Journal, 18(2), 97-100.

Lubkin, I. M., Larsen, P. D. (2006). Chronic Ilness; Impact and Interventions. United

InSight, Tahun XIII/Nomor 1/Februari 2016 
Stated of America: Jones and Bartlett Publishers Inc.

McDonell, M. G., Short, R. A., Berry, C. M., Dyck, D. G. (2003). Burden in Schizophrenia Caregivers: Impact of Family Psychoeducation and Awareness of Patient Suicidality. Family Process, Vol.42, No.1, 91-103.

McDonell, M. G., Dyck, D.G. (2004). MultipleFamily Group Treatment As An Effective Intervention For Children With Psychological Disorders.Clinical Psychology Review, 24, 685-706.

Nichols, M.P., Schwartz, R.C. (2007). The Essentials of Family Therapy. United States of America:Pearson Education, Inc.

Permanasari, I., Tunggal, N.(2013). Bicara Tentang Jiwa Terpecah. Kompas-online. Psikologi Artikel. Selasa, 5 Oktober2010. Diunduh tanggal 19 Januari 2011, dari http://health.kompas.com/read/2010/10/05 /07092282/Bicara.tentang.Jiwa.Terpecah.
Santoso, S. (2014). Statistik Parametrik, Konsep dan Aplikasi Dengan SPSS, Edisi Revisi. Jakarta: PT Gramedia.

Smith, T. E., Weston, C. A., Lieberman, J. A. (2009). Schizophrenia (Maintenance Treatment). BMJ, Clinical Evidence, 04:1007, 1-21.

Talwar, P., Matheiken, S. T. (2010). Caregivers in schizophrenia: a cross cultural perspective. Indian Journal of Psychological Medicine, 32(1), 29-33.

Widyanti, R. N. (2009). Gambaran Kebahagiaandan Karakteristik Positif pada Wanita Dewasa Madya yang Menjadi Caregiver InformalPenderita Skizofrenia.Skripsi. FakultasPsikologi Universitas Indonesia. 